\title{
The fate of minor alkali elements in the chemical evolution of salt lakes
}

Rebecca A Witherow ${ }^{1,2,3}$ and W Berry Lyons ${ }^{1,2^{*}}$

\begin{abstract}
Alkaline earth elements and alkali metals ( $\mathrm{Mg}, \mathrm{Ca}, \mathrm{Na}$ and $\mathrm{K}$ ) play an important role in the geochemical evolution of saline lakes as the final brine type is defined by the abundance of these elements. The role of major ions in brine evolution has been studied in great detail, but little has been done to investigate the behaviour of minor alkali elements in these systems despite their similar chemical affinities to the major cations. We have examined three major anionic brine types, chloride, sulphate, and bicarbonate-carbonate, in fifteen lakes in North America and Antarctica to determine the geochemical behaviour of lithium, rubidium, strontium, and barium. Lithium and rubidium are largely conservative in all water types, and their concentrations are the result of long-term solute input and concentration through evaporation and/or sublimation. Strontium and barium behaviours vary with anionic brine type. Strontium can be removed in sulphate and carbonate-rich lakes by the precipitation of carbonate minerals. Barium may be removed in chloride and sulphate brines by either the precipitation of barite and perhaps biological uptake.
\end{abstract}

\section{Background}

The ultimate chemistry of a saline, closed-basin lake is determined by the initial composition of precipitation, the weathering reactions between dilute inflow water and lithology, and evapoconcentration (or sublimation) of the lake water [1]. The chemical pathways of evolving brines, termed geochemical divides, are determined very early by the initial chemical composition [1]. During mineral precipitation from a brine, the less abundant ion of the mineral pair of ions will become drastically depleted compared to the other [1].

Modelling of closed-basin lakes has focused on the major elements of most natural waters: $\mathrm{Ca}, \mathrm{Na}, \mathrm{K}, \mathrm{Mg}$, $\mathrm{Cl}, \mathrm{SO}_{4}$, and carbonate alkalinity $\left(\mathrm{HCO}_{3}+\mathrm{CO}_{3}\right)$ and the simple salts that these ions produced during evaporation [1-3]. This research was fundamental in illustrating how the geochemistry of a lake can result from dilute inflow water with a composition unlike the final brine. It is clear from these models that the abundance of major alkali elements, $\mathrm{Ca}, \mathrm{Na}, \mathrm{K}$, and $\mathrm{Mg}$, is key in determining the geochemical pathways involved in brine formation, yet there has been little work to extend the modelling efforts to aid in the prediction of minor and trace metal behaviour

\footnotetext{
* Correspondence: lyons.142@osu.edu

${ }^{1}$ School of Earth Sciences, The Ohio State University, Columbus, Ohio, USA Full list of author information is available at the end of the article
}

during brine formation. In this paper, we have made an attempt to understand minor alkali metal and alkaline earth behaviour in different brine types in order to extend the earlier efforts on major cations. We have analysed water samples from brackish and saline lakes in the Great Basin of the United States, Saskatchewan, and the McMurdo Dry Valleys of Antarctica (Figure 1) and used these data in the geochemical model, PHREEQ, to illustrate the potential removal mechanisms that are occurring in closed-basin lakes.

\section{Site descriptions \\ McMurdo Dry Valleys}

The McMurdo Dry Valleys (MCM) are the largest ice-free areas in Antarctica (approximately $4800 \mathrm{~km}^{2}$ ) (Figure 1) [4]. The MCM $\left(\approx 78^{\circ} S\right)$ are a polar desert classified by extremely low average annual temperatures $\left(-16^{\circ} \mathrm{C}\right.$ to $\left.-21^{\circ} \mathrm{C}\right)$ and high aridity $(<10 \mathrm{~cm}$ snowfall per year) [5]. Even in these harsh conditions, perennially ice-covered lakes and hypersaline ponds exist in Taylor Valley (Lakes Fryxell, Hoare, and Bonney) and in Wright Valley (Lake Vanda and Don Juan Pond) [6].

The ephemeral streams in the MCM flow between 6-10 weeks during the austral summer from November to January and flow is highly variable both daily and seasonally $[5,7]$. The water in these ephemeral streams is
C Biomed Central

(c) 2011 Witherow and Lyons; licensee BioMed Central Ltd. This is an Open Access article distributed under the terms of the Creative Commons Attribution License (http://creativecommons.org/licenses/by/2.0), which permits unrestricted use, distribution, and reproduction in any medium, provided the original work is properly cited. 


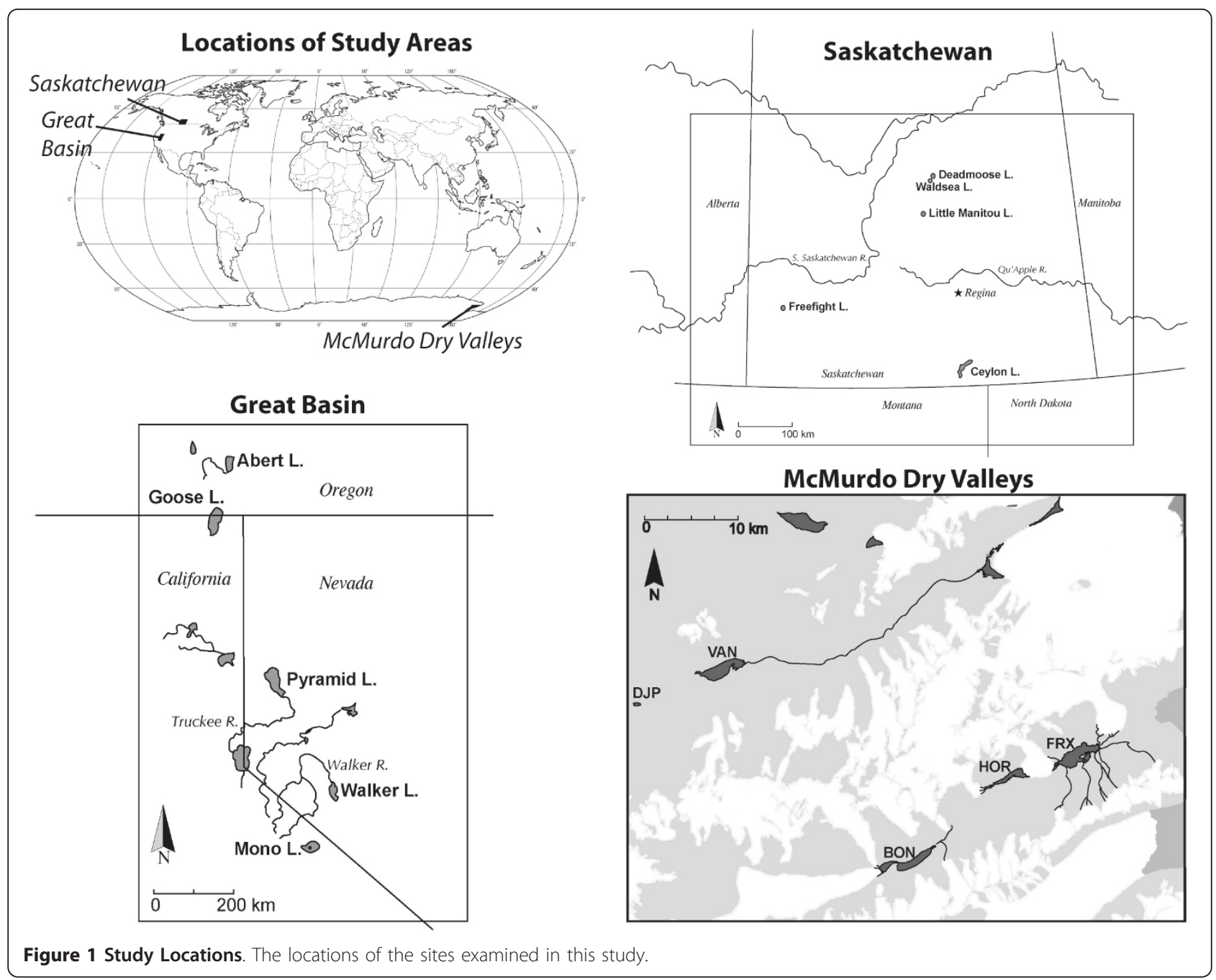

derived from glacial melt and it is the sole source of water to closed-basin lakes of the MCM. The only means of maintaining hydrological balance in the lakes is by sublimation of the perennial ice covers, which are replenished by the freezing of lake water on the bottom of the ice [8].

Previous work on the MCM lakes has shown that despite the great range in salinity (TDS $=40-645,000 \mathrm{mg} / \mathrm{L}$ ), all of the $\mathrm{MCM}$ lakes have $\mathrm{Cl}$ as the major anion $[9,10]$. The glacial melt inflow is enriched in marine aerosols, and the dissolution of aeolian-deposited marine salts contributes to enrichment in chloride $[10,11]$. Sodium is the dominant cation in the Taylor Valley Lakes (Bonney, Fryxell, and Hoare) and $\mathrm{Ca}$ is the dominant cation in Lake Vanda's hypolimnion and Don Juan Pond [12,13].

\section{Great Basin lakes}

The geochemistry of Great Basin lakes has been studied in great detail and was key in developing the brine evolution model [14]. Mono Lake, Pyramid Lake, and Walker Lake, are the remnants of Pleistocene Lake Lahontan
(Figure 1), and are characterized by relatively high concentrations of carbonate and bicarbonate. As these lakes evaporated, calcium and magnesium were removed as sulphate and carbonate minerals, drastically depleting the lakes of alkaline earth elements [14]. Lake Abert, in southern Oregon, and Goose Lake, on the border between Oregon and California, are remnants of Pleistocene Lake Chewaucan (Figure 1). Mean annual temperatures in the northern reaches of the Great Basin range from $23^{\circ}$ to $32^{\circ} \mathrm{C}$, and the majority of water entering these lakes comes from seasonal snowmelt in the surrounding mountains [15]. Lake Abert is a $\mathrm{Na}-\mathrm{Cl}-\mathrm{CO}_{3}$ brine with TDS ranging from 18,700-95,000 mg/L. Because it has been periodically refreshed by overflow, Goose Lake, a Na- $\mathrm{HCO}_{3}$ brine, is much fresher with TDS ranging from 600 to $2,700 \mathrm{mg} / \mathrm{L}$. The wide range in salinities in these lakes is due to climatic conditions and anthropogenic activities which dictate the balance of evaporation and inflow. In Abert and Goose Lakes, it has been suggested that carbonates and silicates are being 
removed by inorganic precipitation and biogenic processes [15].

\section{Canadian Prairie lakes}

It is estimated that the Great Plains of Canada have between one and ten million saline lakes (Figure 1) [16]. The lakes are young $(<10,000$ years old), and most are remnants of larger extinct proglacial lakes such as Lake Regina, Lake Hind, Lake Saskatchewan, and Lake Agassiz [16]. The area is characterized as a cold, semi-arid climate, and although the mean annual temperature is $3^{\circ} \mathrm{C}$, the low humidity, high winds, and warm summer temperatures are conducive to high evaporation rates [17]. During the cold, clear winter months, many lakes form an ice cover, and some lakes have undergone periodic desiccation and refilling [16,18].

The lakes show a wide range in salinity from brackish (TDS $=1,000-5,000 \mathrm{mg} / \mathrm{L}$ ) to saline (TDS $>5,000 \mathrm{mg} / \mathrm{L}$ ) [16]. Sulphate along with $\mathrm{Mg}, \mathrm{Ca}$, and $\mathrm{Cl}$ demonstrate considerable range and relative concentrations between lakes [17]. Ceylon Lake, Freefight Lake, and Waldsea Lake are dominated by sulphate and Deadmoose Lake and Little Manitou Lake are mixed $\mathrm{SO}_{4}$ - $\mathrm{Cl}$ brines. In all of the lakes, sodium is the dominant cation indicating that either the inflow waters were highly depleted in calcium and magnesium and/or that these cations have been removed by the precipitation salts. The larger, perennial lakes are chemically and thermally stratified with complex mineral precipitation/dissolution profiles [18]. The lakes precipitate calcite and high magnesium calcite and periodic whiting has been observed in Deadmoose and Waldsea Lakes $[16,17]$.

All of these lakes in this study were selected because they are brackish to hypersaline or, in the case of MCM lakes, their hypolimnia are brackish or hypersaline. Because their major anion concentrations vary greatly, the comparison of these very different closed-basin systems provide an excellent test of the importance of anionic composition on minor-element distribution and potential mineral precipitation.

\section{Results}

\section{Concentrations: Major elements}

The salinities, as TDS, of the Canadian lakes ranged from 2.7\% (Deadmoose Lake) to 23\%. (Ceylon Lake) (Additional file 1). The salinities of the lakes in the Great Basin ranged from $0.4 \%$ (Pyramid Lake) to 12\% (Abert Lake). The range of the salinity of the MCM lakes was $0.003 \%$ to $44 \%$ with the lowest values in the surface water of Lake Hoare and the highest salinity in Don Juan Pond.

Sodium was the dominant cation in all of the lakes in the MCM with the exception the hypolimnion of Lake Vanda and Don Juan Pond, where Ca was dominant. Na concentrations ranged from $20.3 \mathrm{mg} / \mathrm{L}$ in the surface water of Lake Hoare to $48,500 \mathrm{mg} / \mathrm{L}$ at $35 \mathrm{~m}$ in E. Lake
Bonney. All of the McMurdo Dry Valley lakes/ponds had chloride as the dominant anion. The water at $4 \mathrm{~m}$ in Lake Hoare had the lowest concentrations of $\mathrm{Cl}(33.5$ $\mathrm{mg} / \mathrm{L}$ ), and Don Juan Pond had the highest $\mathrm{Cl}$ concentrations of all lakes in the MCM $(283,000 \mathrm{mg} / \mathrm{L})$. Na was the dominant cation in the Canadian lakes where concentrations ranged from $2,160 \mathrm{mg} / \mathrm{L}$ in Waldsea Lake to 196,000 mg/L in Ceylon Lake. Sulphate concentrations ranged from 14,800 $\mathrm{mg} / \mathrm{L}$ in Deadmoose Lake to 196,000 $\mathrm{mg} / \mathrm{L}$ in Ceylon Lake. The highest concentration of $\mathrm{Cl}$ was in Little Manitou Lake (21,300 mg/L), and the lowest concentration occurred in Freefight Lake $(4,190 \mathrm{mg} / \mathrm{L})$. The lakes in the Great Basin had $\mathrm{Na}$ as the dominant cation. Mono Lake had the highest Ca concentrations, $3.7 \mathrm{mg} / \mathrm{L}$. Ca was below the detection limit in Abert Lake; this has been shown in previous work as well [19]. Mono and Goose Lakes were carbonate-rich, Pyramid Lake was chloride-rich, and Abert and Walker Lakes were enriched in both $\mathrm{HCO}_{3}+\mathrm{CO}_{3}$ and $\mathrm{Cl}$. The $\mathrm{pH}$ values in the MCM lakes were generally lower than the lakes in Saskatchewan, which were lower than the alkaline lakes of the Great Basin.

The major element geochemistry of all these lakes are depicted in Piper diagrams in Figure 2. (We have utilized Piper diagrams to visually demonstrate the difference in the major ion geochemistry of the three different lakes settings and to show the impact of the changes in anion dominance on the major cation geochemistry). Of all the lakes studied, the Great Basin lakes had the highest concentrations of $\mathrm{HCO}_{3}+\mathrm{CO}_{3}$, and the Saskatchewan lakes had the highest concentrations of $\mathrm{SO}_{4}$. The hypersaline waters of the MCM had the highest $\mathrm{Cl}, \mathrm{Ca}$, and $\mathrm{Mg}$ concentrations, and their surface, fresher waters had the lowest. So, for simplicity we shall term the Great Basin lakes, the "carbonate lakes," the Saskatchewan lakes, the "sulphate lakes," and the McMurdo Dry Valley lakes, the "chloride lakes."

\section{Concentrations: Minor elements}

Of the minor elements, $\mathrm{Li}, \mathrm{Rb}, \mathrm{Sr}$, and $\mathrm{Ba}$, the Canadian and Great Basin lakes had $\mathrm{Li}$ in the highest concentration except Walker Lake which had Sr concentrations higher than Li (Additional file 2). Lake Hoare, Lake Fryxell, and West Lake Bonney are described by high concentrations of Sr. Lake Vanda, Don Juan Pond, and the monimolimnion of East Lake Bonney had high concentrations of Li and $\mathrm{Sr}$. In general $\mathrm{Li}$ and $\mathrm{Rb}$ demonstrated positive relationships with $\mathrm{Cl}$ (Figures 3 and 4). Strontium had a strong relationship with $\mathrm{Ca}$ but a poor relationship with $\mathrm{Cl}$ (Figure 5 and 6). In general, $\mathrm{Ba}$ and $\mathrm{Sr}$ do not correlate well with any major or minor elements including $\mathrm{Cl}$ (Figures 3, 4, 5 and 7). The strong correlations for $\mathrm{Li}$ and $\mathrm{Rb}$ with $\mathrm{Cl}$ suggest conservative behavior of these cations through the evapoconcentration/sublimation process. 


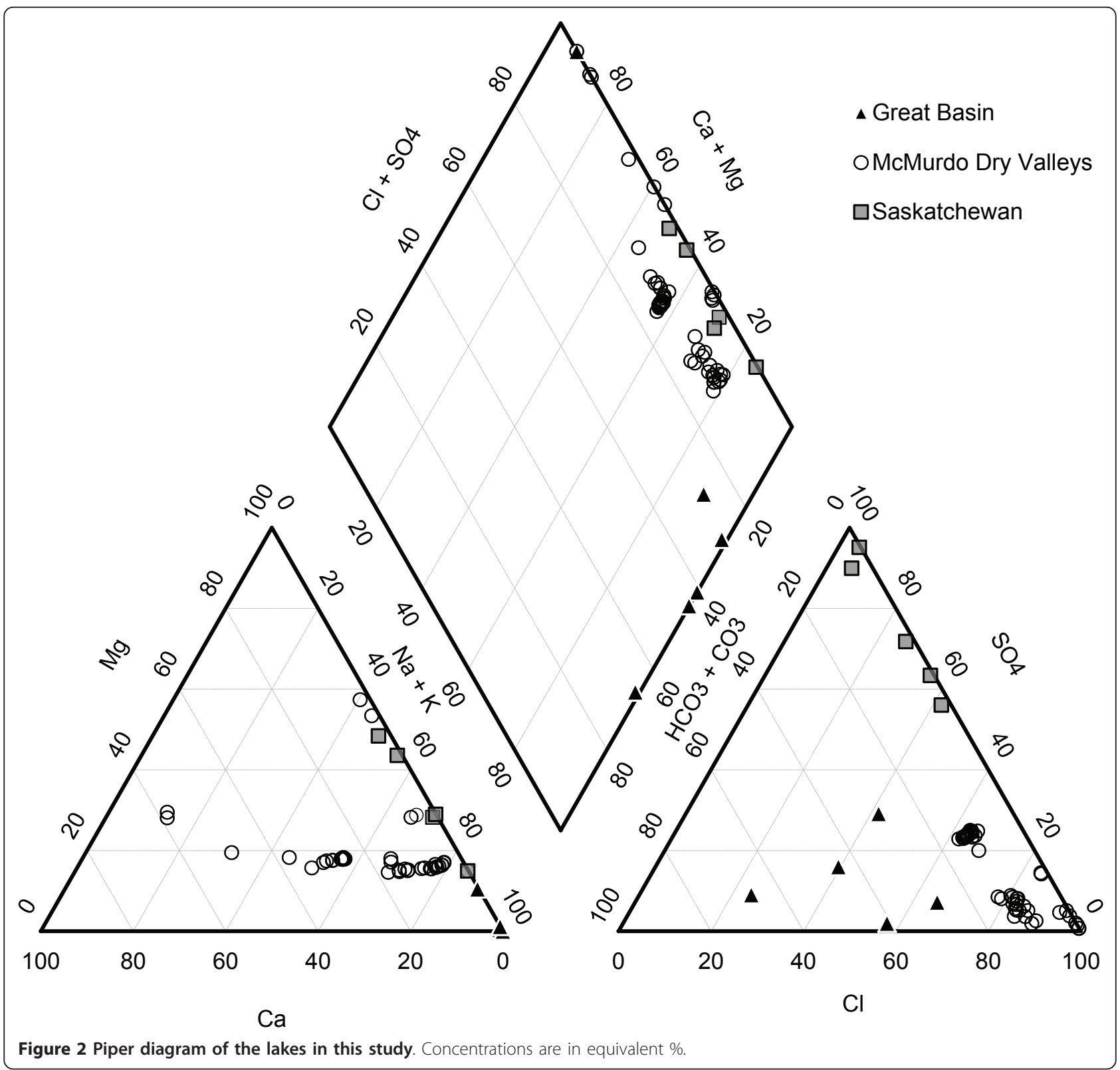

Note that the seawater cation and $\mathrm{Cl}$ values are shown on these plots for reference. There is an apparent relationship between $\mathrm{Ba}$ and $\mathrm{Cl}$ at the lower salinities but this relationship is different among the lakes (Figure 7).

Don Juan Pond had the highest Li $\left(2.65 \times 10^{5} \mu \mathrm{g} / \mathrm{L}\right)$, Sr $\left(1.04 \times 10^{6} \mu \mathrm{g} / \mathrm{L}\right)$, and $\mathrm{Ba}\left(1.4 \times 10^{3} \mu \mathrm{g} / \mathrm{L}\right)$ concentrations of all the MCM lakes (Additional file 2). The highest $\mathrm{Rb}$ concentration $(294 \mu \mathrm{g} / \mathrm{L})$ was found $35 \mathrm{~m}$ below the surface of E. Lake Bonney. Of all the MCM lakes, Lake Hoare, the freshest lake in this study, had the lowest $\mathrm{Li}$ $(2.47 \mu \mathrm{g} / \mathrm{L}), \mathrm{Rb}(2.11 \mu \mathrm{g} / \mathrm{L}), \mathrm{Sr}(150 \mu \mathrm{g} / \mathrm{L})$, and Ba $(1 \mu \mathrm{g} / \mathrm{L})$ concentrations. These occurred at $4 \mathrm{~m}$ depth. In all of the MCM lakes, $\mathrm{Li}, \mathrm{Rb}$, and $\mathrm{Sr}$ increased in concentration with depth. Barium concentrations increased with depth in Lakes Hoare, Fryxell, and Vanda, but the hypolimnetic waters of both lobes of Lake Bonney had concentrations lower than samples from above the chemocline. In the Saskatchewan lakes, Ceylon Lake had the highest concentrations of $\mathrm{Li}\left(1.31 \times 10^{4} \mu \mathrm{g} / \mathrm{L}\right), \mathrm{Rb}(98.8 \mu \mathrm{g} / \mathrm{L})$, and $\mathrm{Sr}$ $\left(3.18 \times 10^{3} \mu \mathrm{g} / \mathrm{L}\right)$. Little Manitou Lake had the highest concentration of $\mathrm{Ba}(54 \mu \mathrm{g} / \mathrm{L})$. Deadmoose Lake had the lowest concentrations of $\mathrm{Li}\left(1.9 \times 10^{3} \mu \mathrm{g} / \mathrm{L}\right), \mathrm{Rb}(20.2 \mu \mathrm{g} /$ $\mathrm{L})$, and $\mathrm{Ba}(16 \mu \mathrm{g} / \mathrm{L})$, and Freefight Lake had the lowest $\mathrm{Sr}$ concentration $(35.1 \mu \mathrm{g} / \mathrm{L})$. In the Great Basin, Mono Lake had the highest concentrations of $\mathrm{Li}\left(9.43 \times 10^{3} \mu \mathrm{g} / \mathrm{L}\right)$ and $\mathrm{Rb}\left(1.63 \times 10^{3} \mu \mathrm{g} / \mathrm{L}\right)$ and Goose Lake had the lowest $(5.90 \mu \mathrm{g} / \mathrm{L}$ and $8.60 \mu \mathrm{g} / \mathrm{L}$, respectively). Goose Lake also had the lowest Ba concentration $(8 \mu \mathrm{g} / \mathrm{L})$. Walker Lake 


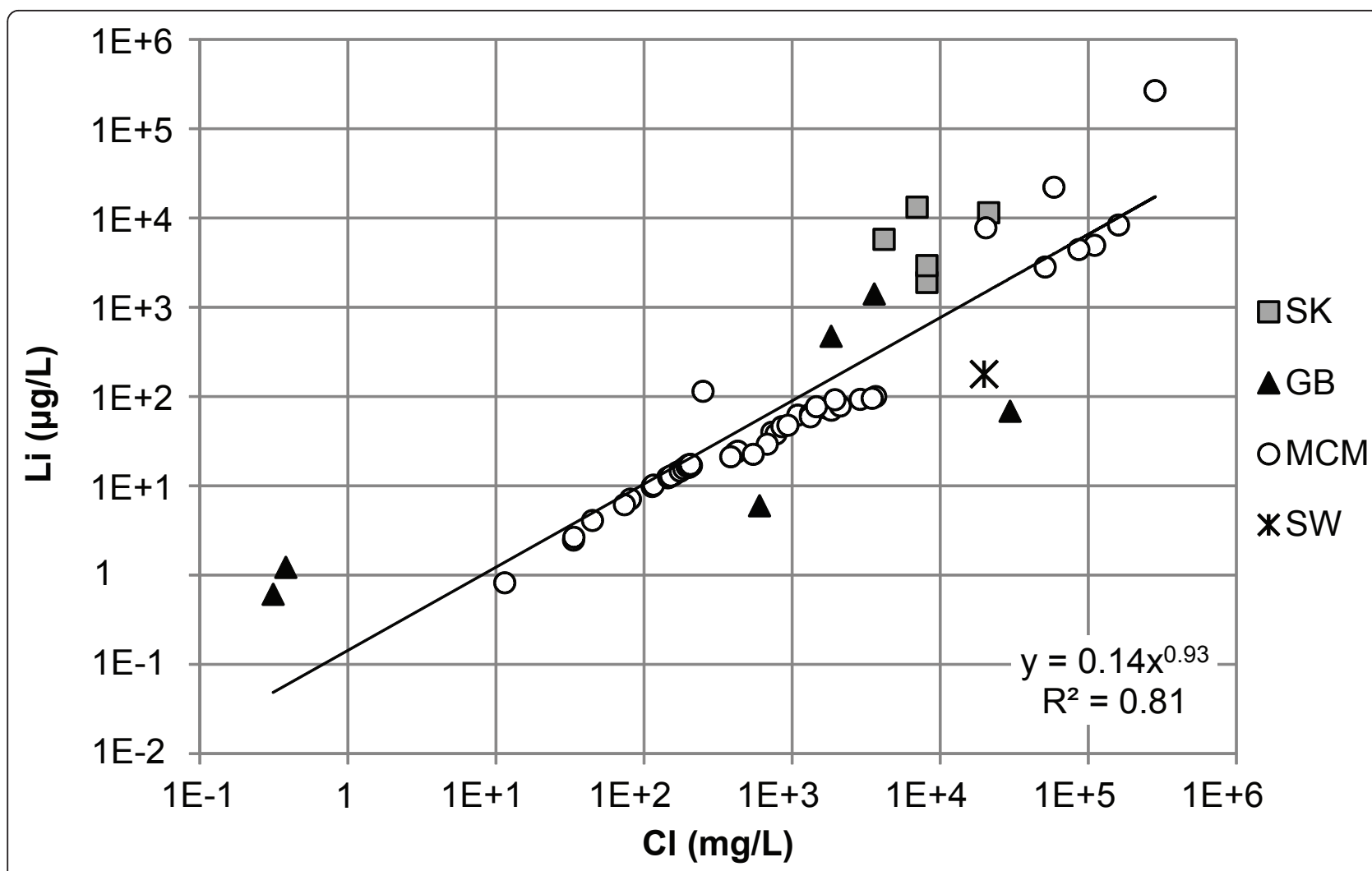

Figure 3 Chloride and lithium concentrations in the lakes in this study. SK = Saskatchewan, GB = Great Basin, MCM = MCMurdo Dry Valleys, SW = seawater [61].

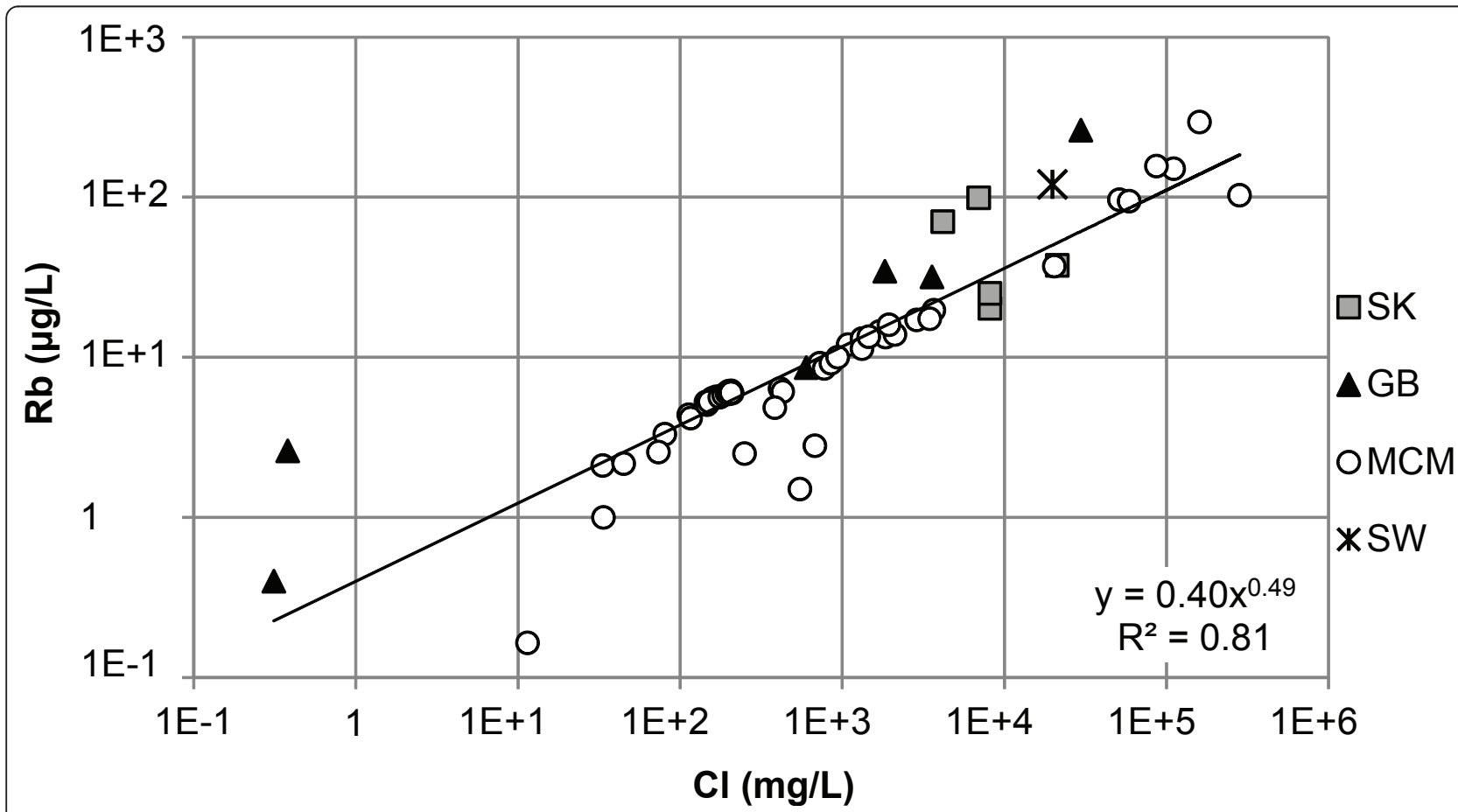

Figure 4 Chloride and rubidium concentrations in the lakes in this study. SK = Saskatchewan, GB = Great Basin, MCM = McMurdo Dry Valleys, SW = seawater [61]. 


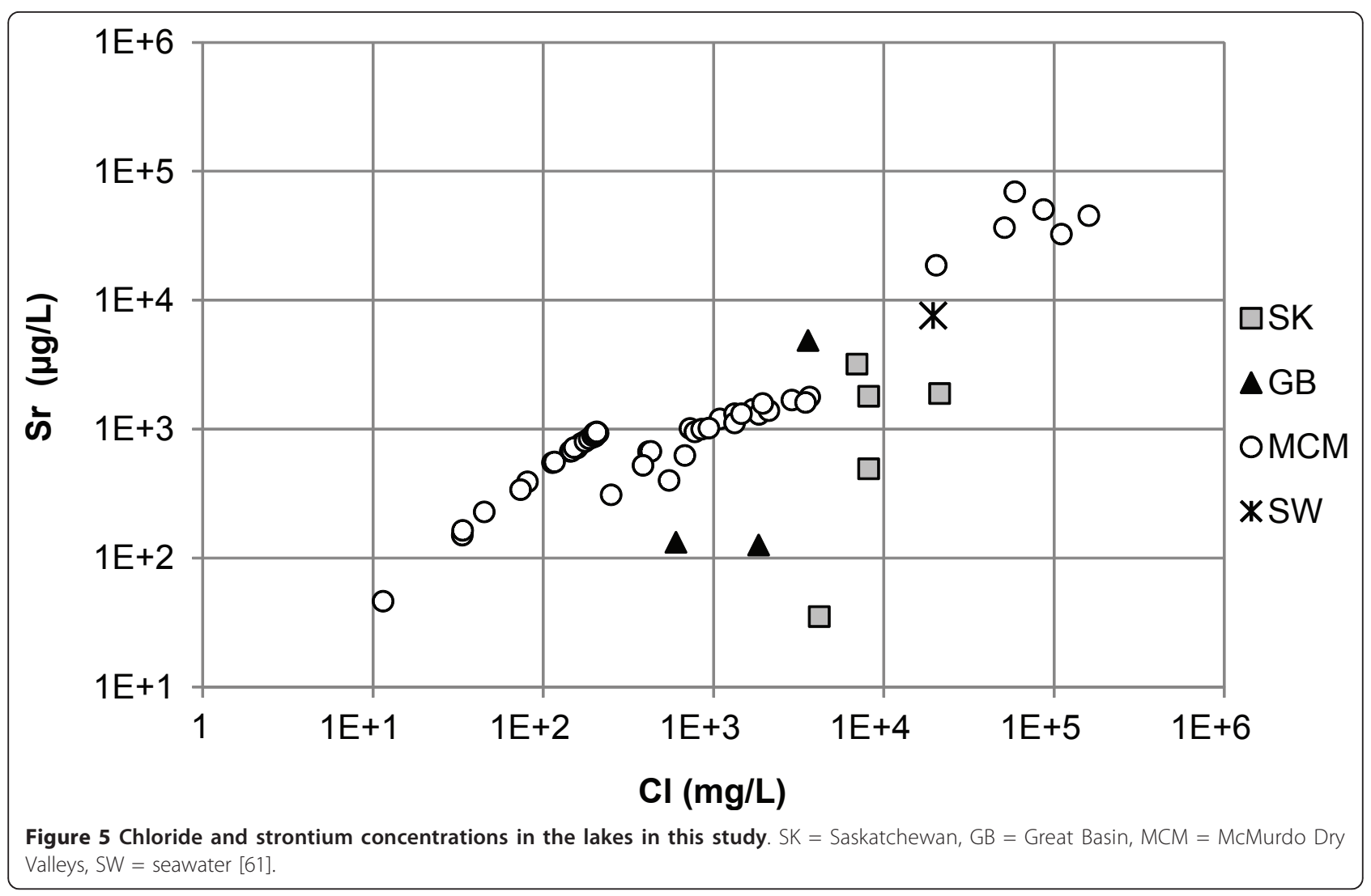

had the highest concentration of $\mathrm{Ba}(160 \mu \mathrm{g} / \mathrm{L})$ and $\mathrm{Sr}\left(4.85 \times 10^{3} \mu \mathrm{g} / \mathrm{L}\right)$. The $\mathrm{Sr}$ concentrations of Mono Lake and Abert Lake were below our detection limit of $0.05 \mu \mathrm{g} / \mathrm{L}$.

\section{PHREEQ modelling}

In order to establish if the geochemistry of the salt lakes in our study is controlled by salt formation, we have used the computer program PHREEQ to determine mineral saturation indices within the lake waters (see Methods for details) (Additional file 3). Although the model calculates the saturation states of a large suite of minerals, we have focused on only the simple binary salts of the elements of interest which include: anhydrite $\left(\mathrm{CaSO}_{4}\right)$, aragonite $\left(\mathrm{CaCO}_{3}\right)$, barite $\left(\mathrm{BaSO}_{4}\right)$, calcite $\left(\mathrm{CaCO}_{3}\right)$, celestite $\left(\mathrm{SrSO}_{4}\right)$, magnesite $\left(\mathrm{MgCO}_{3}\right)$, strontianite $\left(\mathrm{SrCO}_{3}\right)$ and witherite $\left(\mathrm{BaCO}_{3}\right)$. The hydrated salts, gypsum $\left(\mathrm{CaSO}_{4} \cdot 2 \mathrm{H}_{2} \mathrm{O}\right)$ and mirabilite $\left(\mathrm{Na}_{2} \mathrm{SO}_{4} \cdot 10 \mathrm{H}_{2} \mathrm{O}\right)$ play a critical role in the evolution of many saline waters and are also included in our calculations. The MCM calculations were performed using in-situ measured temperatures. Because we did not have the temperatures of the samples when they were obtained, we calculated saturation indices for the Great Basin and Saskatchewan lakes at two end member temperatures, $0^{\circ} \mathrm{C}$ and $20^{\circ} \mathrm{C}$ in order to examine how seasonal temperature variations might affect mineral precipitation within the lakes.

\section{Modelling results}

The saturation indices for all the lakes are tabulated in Table 1 . The Canadian Lakes were all supersaturated with respect to magnesite at $0^{\circ} \mathrm{C}$ and $20^{\circ} \mathrm{C}$ (Table 1 ). Waldsea Lake was supersaturated with aragonite, barite, and calcite at $0^{\circ} \mathrm{C}$ and $20^{\circ} \mathrm{C}$. Little Manitou and Deadmoose Lakes were supersaturated with barite at $0^{\circ} \mathrm{C}$ and $20^{\circ} \mathrm{C}$, supersaturated with respect to calcite at $20^{\circ} \mathrm{C}$, and were in near equilibrium with aragonite at $20^{\circ} \mathrm{C}$. At $0^{\circ} \mathrm{C}$, Little Manitou and Deadmoose Lakes were undersaturated with calcite and aragonite. With respect to barite, Freefight and Ceylon Lakes were near equilibrium at $20^{\circ} \mathrm{C}$ and supersaturated at $0^{\circ} \mathrm{C}$. At $0^{\circ} \mathrm{C}$, Ceylon Lake was the only lake in this study to be supersaturated with mirabilite.

All of the lakes sampled in the Great Basin were supersaturated with respect to calcite and magnesite at $0^{\circ} \mathrm{C}$ and $20^{\circ} \mathrm{C}$ (calculations for Abert Lake were not attempted due to the undetectable $\mathrm{Ca}$ concentrations). All lakes except Pyramid Lake were supersaturated with aragonite at $0^{\circ} \mathrm{C}$ and $20^{\circ} \mathrm{C}$. Pyramid Lake was supersaturated with aragonite at $20^{\circ} \mathrm{C}$, but it was in approximate equilibrium at $0^{\circ} \mathrm{C}$. Pyramid Lake was also near equilibrium with respect to barite 


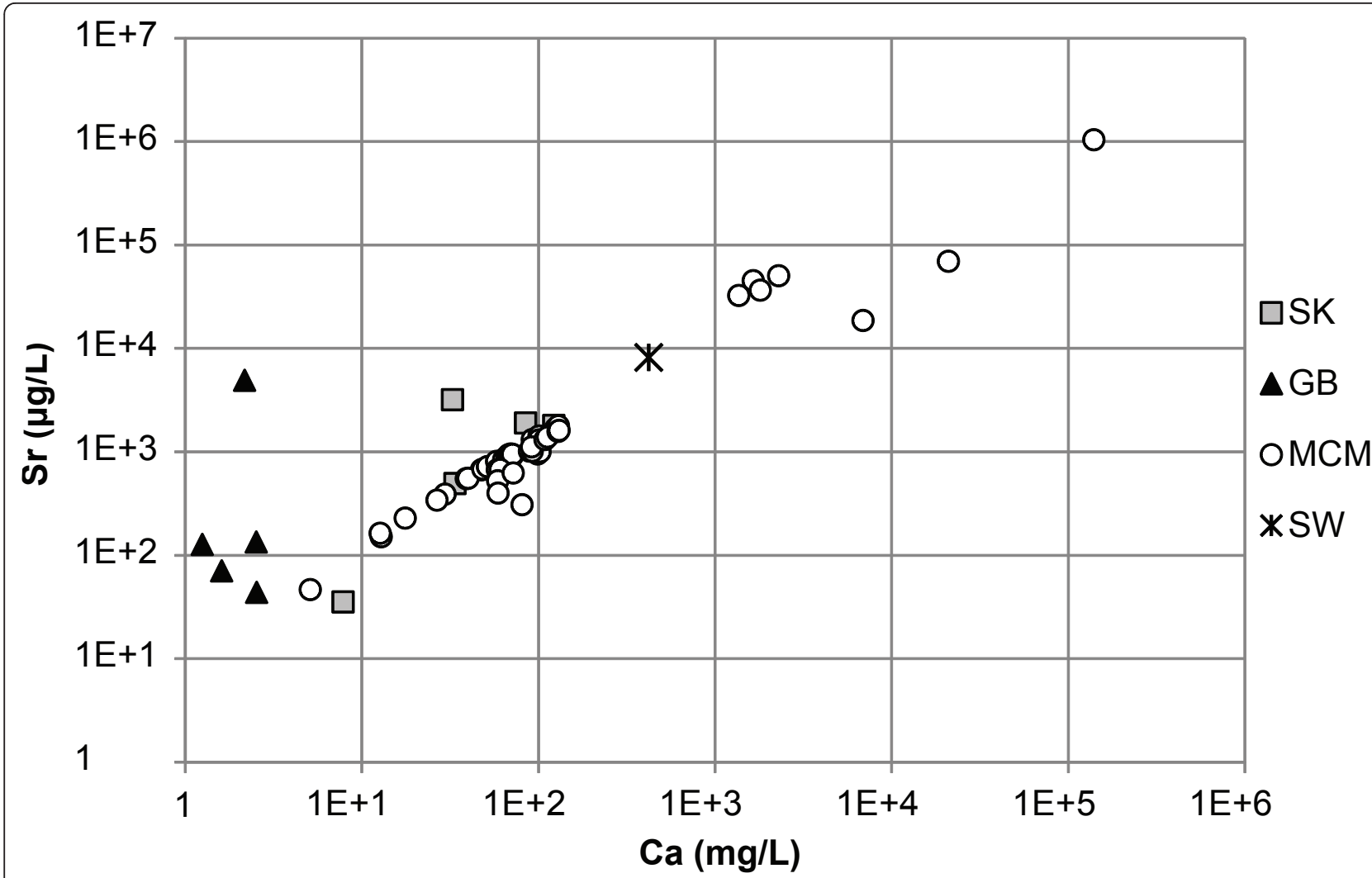

Figure 6 Calcium and strontium concentrations in the lakes in this study. SK = Saskatchewan, GB = Great Basin, MCM = McMurdo Dry Valleys, SW = seawater [61].

at $20^{\circ} \mathrm{C}$. Walker and Goose Lakes were supersaturated with strontianite at $0^{\circ} \mathrm{C}$ and $20^{\circ} \mathrm{C}$, and strontianite was in near equilibrium at $20^{\circ} \mathrm{C}$ in Pyramid Lake.

The lakes in the McMurdo Dry Valleys have been sampled in such a way that their saturation indices in profile could be examined at in-situ temperatures (Table 1). Lake Hoare was in near equilibrium with barite at $30 \mathrm{~m}$. Calcite was in near equilibrium in Lake Fryxell at $8 \mathrm{~m}$ and from 12 to $14 \mathrm{~m}$, and barite approached saturation at the sediment-water interface. Barite was in near equilibrium in the bottom water of Lake Vanda. In East Lake Bonney, barite and magnesite were supersaturated only at 22 and $35 \mathrm{~m}$, and calcite and celestite were in near equilibrium at $35 \mathrm{~m}$. In West Lake Bonney, barite was supersaturated at only 15 and $35 \mathrm{~m}$. The profiles of the saturation indices of the various minerals are show in Figure 8.

\section{Discussion}

Because chloride is conservative in most saline lakes, normalizing solute concentration relative to chloride can be used to monitor the progression of evaporation and chemical evolution [2]. $\mathrm{Li}$ and $\mathrm{Rb}$ show strong positive relationships with $\mathrm{Cl}$ indicating that their behaviour is conservative during brine evolution (Figures 3 and 4).
These results suggest that the concentration of $\mathrm{Li}$ and $\mathrm{Rb}$ in all these closed basin lakes is determined by the rockwater interactions in source waters followed by evapoconcentration and that little removal has occurred at the salinities encountered in these lakes. This has previously been argued for $\mathrm{Li}$ in the Antarctic lakes by Lyons and Welch [20]. The McMurdo Valley lakes, in part because there are more cation data, show more richness in their trends. For example, in some samples Rb shows significant depletion relative to the trend with $\mathrm{Cl}$ at the lowest concentrations (Figure 4). This may reflect the dominant rock type in tillage in the watershed and a difference in source. Both $\mathrm{Sr}$ and $\mathrm{Ba}$ have depletions at intermediate $\mathrm{Cl}$ concentrations; the slope of the $\mathrm{Ba}$ vs. $\mathrm{Cl}$ changes little, however the $\mathrm{Sr}$ to $\mathrm{Cl}$ slope does change (Figure 5 and 7). These trends suggest removal of these alkaline earths at these intermediate chloride concentrations $(\sim 200 \mathrm{mg} / \mathrm{L})$ and continued removal of $\mathrm{Sr}$ at even higher Cl concentrations.

\section{Binary salt precipitation}

Strontium shows a poor relationship with $\mathrm{Cl}$ (Figure 5) in the sulphate and carbonate lakes, indicating that strontium does not behave conservatively and is removed 


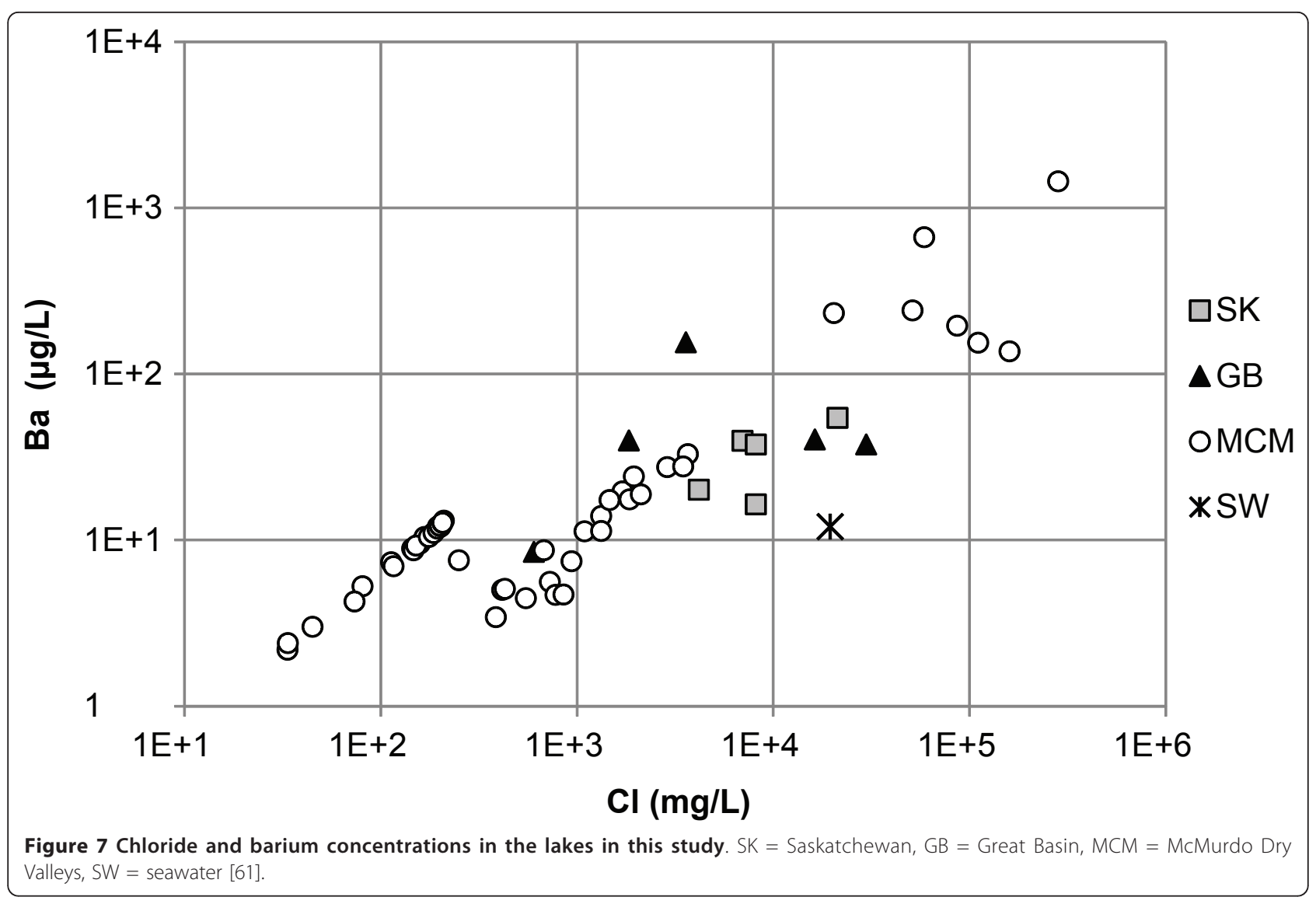

from solution during lake water evolution. In Pyramid Lake, $\mathrm{Ca}, \mathrm{CO}_{3}$, $\mathrm{Sr}$, and $\mathrm{Ba}$ co-vary in deposited lake sediments suggesting a similar removal mechanism [21]. Strontium could form strontianite $\left(\mathrm{SrCO}_{3}\right)$ or celestite $\left(\mathrm{SrSO}_{4}\right)$ or be incorporated into $\mathrm{CaCO}_{3}$, specifically aragonite. Because the Canadian lakes remain undersaturated with respect to strontianite at both $0^{\circ}$ and $20^{\circ} \mathrm{C}$, it is unlikely that $\mathrm{Sr}$ is being removed as either of these minerals (Figure 9). Likewise, data from the McMurdo Dry Valley lakes indicate that the conditions for strontianite precipitation are thermodynamically unfavourable (Figure 8). Walker and Goose Lakes, however, are both supersaturated with respect to strontianite at $0^{\circ} \mathrm{C}$ and $20^{\circ} \mathrm{C}$, and Pyramid Lake is in near equilibrium with strontianite at $0^{\circ} \mathrm{C}$. It is therefore possible that $\mathrm{Sr}$ is removed in Walker and Goose Lakes by strontianite precipitation.

Celestite has been shown to be supersaturated in a hypersaline brine in the Mediterranean Sea and is thought to be a primary $\mathrm{Sr}$ removal mechanism there $[22,23]$. Celestite has been observed in the playa sediments of Bristol Dry Lake, California from the evaporation of saline groundwater discharge, and it is thought to be diagenetic in origin [24]. Celestite can also be produced diagenetically in part through the dolomitization of carbonate minerals
[25]. Our work did not evaluate the lake sediments but was focused on the potential formation of primary, not diagenectically, produced celestite. Ba can also be removed via the diagenetic formation of celestite [25]. In all of the lakes examined in this work, celestite is undersaturated, the only exception being the bottom waters of East Lake Bonney where it is in near equilibrium (Figure 8). This does not rule out the possibility that celestite is forming diagenectically in these systems. Usually the depletion of $\mathrm{Ba}$ and $\mathrm{Sr}$ is coupled with the Ca depletion in a brine, and a continuous series of mineral precipitation from barite to celestite can exist $[26,27]$. In addition to being a removal "sink" for $\mathrm{Ba}$, barite crystals in the ocean contain various amounts of Sr, that may exceed 20\% [28].

The poor relationship of $\mathrm{Ba}$ to $\mathrm{Cl}$ at higher salinities indicates that barium is being removed in some of the lakes (Figure 7). Furthermore, our thermodynamic modelling shows that barite is supersaturated in some of the lakes investigated (Figure 9). Barite has a relatively low solubility and is supersaturated in surface waters such as the Mediterranean Sea and the brine-seawater interface of the Orca Basin in the Gulf of Mexico [22,23,29]. In the open ocean, Ba distributions are primarily influenced by primary production and the formation and dissolution of barite in the water column can lead to complex $\mathrm{Ba}$ 
Table 1 Saturation Indices of Selected Minerals

\begin{tabular}{|c|c|c|c|c|c|c|c|c|c|c|c|}
\hline & $\mathrm{T}^{\circ} \mathrm{C}$ & $\begin{array}{c}\mathrm{CaSO}_{4} \\
\text { Anhydrite }\end{array}$ & $\begin{array}{c}\mathrm{CaCO}_{3} \\
\text { Aragonite }\end{array}$ & $\begin{array}{l}\mathrm{BaSO}_{4} \\
\text { Barite }\end{array}$ & $\begin{array}{l}\mathrm{CaCO}_{3} \\
\text { Calcite }\end{array}$ & $\begin{array}{c}\mathrm{SrSO}_{4} \\
\text { Celestite }\end{array}$ & $\begin{array}{c}\mathrm{CaSO}_{4} \\
\cdot 2 \mathrm{H}_{2} \mathrm{O} \\
\text { Gypsum }\end{array}$ & $\begin{array}{c}\mathrm{MgCO}_{3} \\
\text { Magnesite }\end{array}$ & $\begin{array}{c}\mathrm{Na}_{2} \mathrm{SO}_{4} \\
\cdot 10 \mathrm{H}_{2} \mathrm{O} \\
\text { Mirabilite }\end{array}$ & $\begin{array}{c}\mathrm{SrCO}_{3} \\
\text { Strontianite }\end{array}$ & $\begin{array}{c}\mathrm{BaCO}_{3} \\
\text { Witherite }\end{array}$ \\
\hline $\log K_{s p}$ & & -4.362 & -8.336 & -9.97 & -8.406 & -6.630 & -4.581 & -7.834 & -1.214 & -9.271 & -8.652 \\
\hline \multirow[t]{2}{*}{ Ceylon Lake } & 20 & -1.30 & -1.03 & 0.09 & -0.83 & -0.30 & -1.08 & 1.22 & -0.73 & -1.24 & -4.97 \\
\hline & 0 & -1.31 & -1.43 & 0.59 & -1.22 & -0.17 & -1.11 & 0.96 & 0.25 & -1.29 & -4.98 \\
\hline \multirow[t]{2}{*}{ Deadmoose Lake } & 20 & -1.44 & -0.08 & 0.28 & 0.12 & -1.32 & -1.20 & 1.25 & -2.74 & -1.17 & -3.69 \\
\hline & 0 & -1.33 & -0.37 & 0.73 & -0.17 & -1.23 & -1.10 & 0.97 & -1.69 & -1.28 & -3.76 \\
\hline \multirow[t]{2}{*}{ Freefight Lake } & 20 & -2.01 & -0.67 & 0.02 & -0.48 & -2.35 & -1.77 & 2.02 & -1.54 & -2.24 & -3.98 \\
\hline & 0 & -1.95 & -1.03 & 0.50 & -0.82 & -2.24 & -1.74 & 1.74 & -0.52 & -2.32 & -4.01 \\
\hline \multirow[t]{2}{*}{ Little Manitou Lake } & 20 & -0.93 & -0.09 & 0.62 & 0.10 & -0.62 & -0.70 & 1.57 & -2.12 & -0.99 & -3.88 \\
\hline & 0 & -0.85 & -0.41 & 1.07 & -0.21 & -0.52 & -0.64 & 1.29 & -1.09 & -1.09 & -3.93 \\
\hline \multirow[t]{2}{*}{ Waldsea Lake } & 20 & -0.84 & 0.63 & 0.55 & 0.82 & -0.71 & -0.6 & 1.85 & -2.71 & -0.46 & -3.31 \\
\hline & 0 & -0.75 & 0.33 & 1.01 & 0.54 & -0.62 & -0.52 & 1.59 & -1.66 & -0.54 & -3.36 \\
\hline \multirow[t]{2}{*}{ Mono Lake } & 20 & -6.49 & 0.96 & -3.03 & 1.15 & ND & -6.24 & 1.20 & -10.11 & ND & -0.92 \\
\hline & 0 & -6.25 & 0.94 & -2.40 & 1.14 & ND & -6.03 & 1.23 & -8.84 & ND & -0.66 \\
\hline \multirow[t]{2}{*}{ Pyramid Lake } & 20 & -3.73 & 0.11 & -0.01 & 0.30 & -2.71 & -3.48 & 1.45 & -5.14 & -0.09 & -1.50 \\
\hline & 0 & -3.54 & -0.09 & 0.49 & 0.12 & -2.59 & -3.31 & 1.23 & -4.08 & -0.14 & -1.50 \\
\hline \multirow[t]{2}{*}{ Walker Lake 5 m } & 20 & -5.99 & 0.66 & -1.73 & 0.85 & -3.51 & -5.74 & 1.92 & -11.11 & 1.92 & -0.42 \\
\hline & 0 & -5.71 & 0.57 & -1.13 & 0.78 & -3.27 & -5.48 & 1.84 & -9.99 & 2.01 & -0.29 \\
\hline \multirow[t]{2}{*}{ Abert Lake } & 20 & $\mathrm{ND}$ & ND & -4.03 & ND & ND & ND & ND & -10.73 & ND & -0.93 \\
\hline & 0 & ND & ND & -3.41 & ND & ND & ND & ND & -9.48 & ND & -0.67 \\
\hline \multirow[t]{2}{*}{ Goose Lake } & 20 & -3.79 & 0.71 & -0.90 & 0.90 & -2.94 & -3.54 & 0.43 & -5.16 & 0.35 & -1.73 \\
\hline & 0 & -3.53 & 0.62 & -0.32 & 0.83 & -2.71 & -3.30 & 0.35 & -4.04 & 0.44 & -1.61 \\
\hline Lake Hoare 4 m & & -3.16 & -0.89 & -1.40 & -0.68 & -3.18 & -2.93 & -1.58 & -7.63 & -1.92 & -4.57 \\
\hline Lake Hoare 5 m & & -2.85 & -0.75 & -1.10 & -0.54 & -2.83 & -2.62 & -1.36 & -7.07 & -1.74 & -4.44 \\
\hline Lake Hoare 6 m & & -2.44 & -0.44 & -0.67 & -0.24 & -2.41 & -2.20 & -1.00 & -6.31 & -1.43 & -4.12 \\
\hline Lake Hoare 8 m & & -2.22 & -0.39 & -0.44 & -0.18 & -2.17 & -1.99 & -0.90 & -5.88 & -1.35 & -4.05 \\
\hline Lake Hoare 10 m & & -2.09 & -0.61 & -0.31 & -0.41 & -2.03 & -1.85 & -1.11 & -5.61 & -1.57 & -4.28 \\
\hline Lake Hoare 12 m & & -2.03 & -0.68 & -0.26 & -0.47 & -1.98 & -1.80 & -1.17 & -5.51 & -1.65 & -4.36 \\
\hline Lake Hoare 14 m & & -1.99 & -0.92 & -0.22 & -0.72 & -1.95 & -1.75 & -1.42 & -5.42 & -1.90 & -4.60 \\
\hline Lake Hoare 16 m & & -1.90 & -1.04 & -0.13 & -0.83 & -1.87 & -1.67 & -1.54 & -5.27 & -2.02 & -4.71 \\
\hline Lake Hoare 18 m & & -1.88 & -1.18 & -0.12 & -0.98 & -1.86 & -1.65 & -1.68 & -5.25 & -2.17 & -4.87 \\
\hline Lake Hoare 20 m & & -1.87 & -1.22 & -0.12 & -1.01 & -1.86 & -1.64 & -1.71 & -5.22 & -2.21 & -4.91 \\
\hline Lake Hoare $22 \mathrm{~m}$ & & -1.88 & -1.26 & -0.11 & -1.06 & -1.85 & -1.64 & -1.76 & -5.21 & -2.25 & -4.95 \\
\hline Lake Hoare 25 m & & -1.86 & -1.32 & -0.11 & -1.12 & -1.85 & -1.63 & -1.83 & -5.20 & -2.32 & -5.02 \\
\hline
\end{tabular}


Table 1 Saturation Indices of Selected Minerals (Continued)

\begin{tabular}{|c|c|c|c|c|c|c|c|c|c|c|}
\hline Lake Hoare 30 m & -1.85 & -1.40 & -0.09 & -1.19 & -1.84 & -1.62 & -1.90 & -5.17 & -2.39 & -5.08 \\
\hline Lake Fryxell $6 \mathrm{~m}$ & -2.66 & -0.55 & -1.19 & -0.34 & -2.70 & -2.43 & -0.92 & -5.39 & -1.59 & -4.53 \\
\hline Lake Fryxell 7 m & -2.65 & -0.40 & -1.21 & -0.19 & -2.70 & -2.42 & -0.75 & -5.38 & -1.46 & -4.40 \\
\hline Lake Fryxell $8 \mathrm{~m}$ & -2.42 & -0.27 & -1.08 & -0.07 & -2.45 & -2.18 & -0.57 & -4.86 & -1.34 & -4.38 \\
\hline Lake Fryxell $9 \mathrm{~m}$ & -2.42 & -0.44 & -0.85 & -0.24 & -2.40 & -2.18 & -0.57 & -4.46 & -1.46 & -4.32 \\
\hline Lake Fryxell $10 \mathrm{~m}$ & -2.40 & -0.46 & -0.72 & -0.25 & -2.34 & -2.16 & -0.52 & -4.31 & -1.43 & -4.22 \\
\hline Lake Fryxell $11 \mathrm{~m}$ & -2.41 & -0.35 & -0.62 & -0.14 & -2.35 & -2.16 & -0.33 & -4.10 & -1.33 & -4.00 \\
\hline Lake Fryxell $12 \mathrm{~m}$ & -2.43 & -0.29 & -0.69 & -0.09 & -2.41 & -2.19 & -0.24 & -4.11 & -1.32 & -4.00 \\
\hline Lake Fryxell 15 m & -2.46 & -0.15 & -0.64 & 0.06 & -2.43 & -2.22 & 0.01 & -3.79 & -1.16 & -3.78 \\
\hline Lake Fryxell $18 \mathrm{~m}$ & -2.71 & -0.14 & -0.83 & 0.07 & -2.67 & -2.47 & 0.11 & -3.87 & -1.14 & -3.70 \\
\hline Lake Vanda $10 \mathrm{~m}$ & -2.57 & -0.82 & -1.12 & -0.62 & -3.05 & -2.31 & -1.58 & -7.15 & -2.38 & -4.83 \\
\hline Lake Vanda $60 \mathrm{~m}$ & -1.42 & -0.62 & -0.25 & -0.42 & -1.69 & -1.15 & -1.30 & -5.37 & -2.07 & -4.87 \\
\hline Lake Vanda $70 \mathrm{~m}$ & -0.60 & -0.75 & -0.09 & -0.56 & -1.17 & -0.40 & -1.34 & -4.43 & -2.54 & -5.56 \\
\hline East Lake Bonney $6 \mathrm{~m}$ & -1.82 & -0.44 & -0.25 & -0.23 & -1.96 & -1.58 & -0.70 & -4.51 & -1.62 & -4.32 \\
\hline East Lake Bonney $22 \mathrm{~m}$ & -0.58 & -0.89 & 0.59 & -0.68 & -0.42 & -0.47 & 0.37 & -1.42 & -1.76 & -5.16 \\
\hline East Lake Bonney $35 \mathrm{~m}$ & -0.26 & -0.25 & 0.49 & -0.04 & -0.06 & -0.28 & 1.25 & -1.69 & -1.14 & -4.94 \\
\hline West Lake Bonney $5 \mathrm{~m}$ & -1.94 & -0.47 & -0.56 & -0.27 & -2.19 & -1.70 & -0.77 & -4.72 & -1.75 & -4.54 \\
\hline West Lake Bonney $15 \mathrm{~m}$ & -0.53 & -1.01 & 0.99 & -0.80 & -0.30 & -0.33 & -0.59 & -1.08 & -1.79 & -4.93 \\
\hline West Lake Bonney $35 \mathrm{~m}$ & -0.52 & -1.07 & 0.63 & -0.86 & -0.36 & -0.36 & -0.49 & -0.81 & -1.93 & -5.36 \\
\hline Don Juan Pond & -0.37 & ND & -1.69 & ND & -1.25 & -1.26 & ND & -9.61 & ND & ND \\
\hline
\end{tabular}




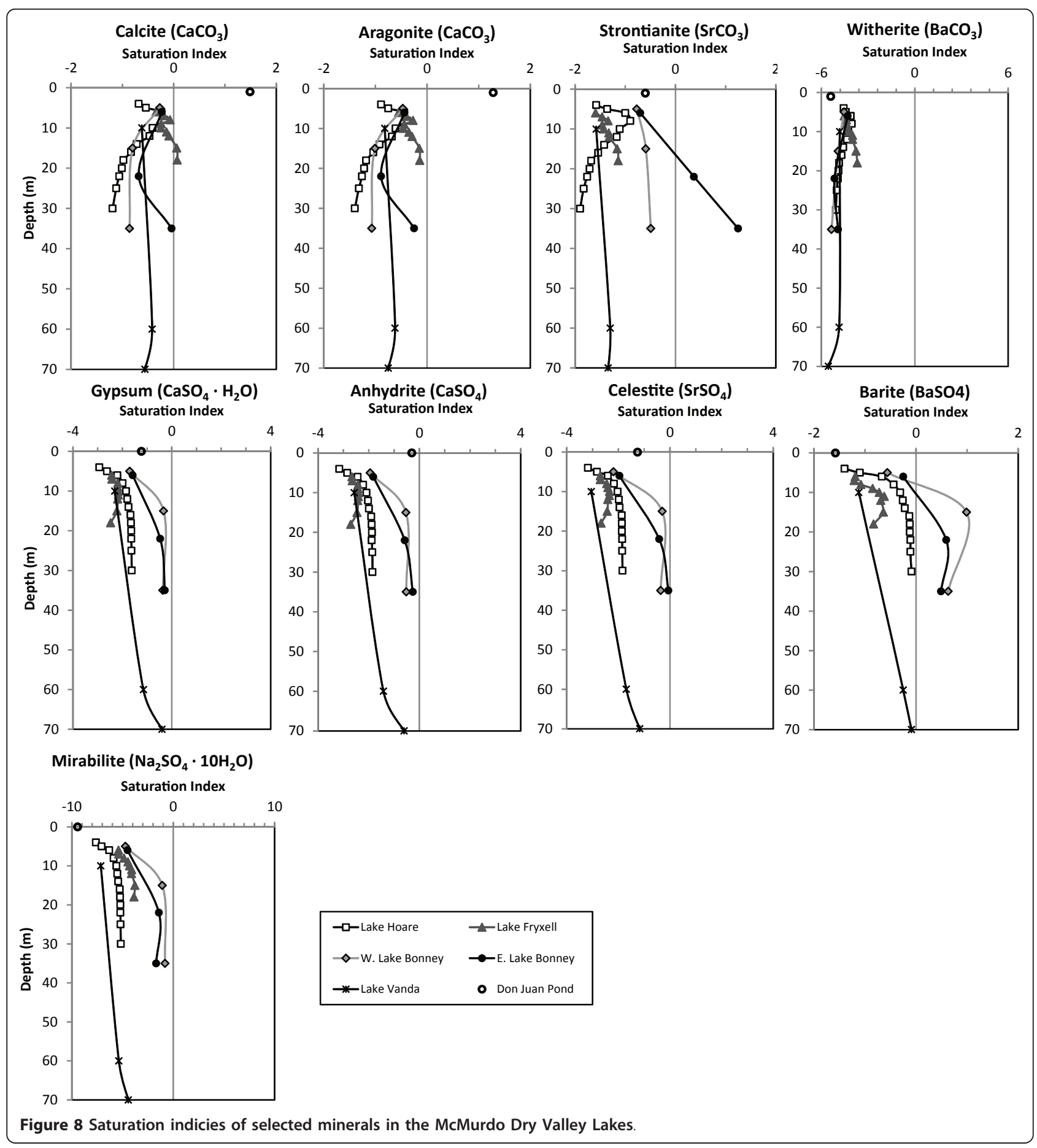

concentration profiles [28,30-32]. In Saskatchewan, Deadmoose, Little Manitou, and Waldsea Lakes are supersaturated with respect to barite at $20^{\circ} \mathrm{C}$, and Ceylon and Freefight Lakes are in near equilibrium at this temperature. However, at $0^{\circ} \mathrm{C}$, all these lakes become supersaturated with respect to barite suggesting that a seasonal precipitation of barite may be an important control on the Ba concentration in the sulphate lakes (Table 1). Winter removal of barite may also be occurring in Pyramid Lake in the Great Basin as it is in equilibrium at $20^{\circ} \mathrm{C}$ but is supersaturated at $0^{\circ} \mathrm{C}$ (Table 1). The geochemical profiles of the McMurdo Dry Valley Lakes give insight into barite removal processes in stratified chloride-type brines (Figure 8). The fresher waters of Lake Hoare and Lake Vanda are undersaturated with respect to barite, but the lake waters approach equilibrium with depth. The surface waters of 


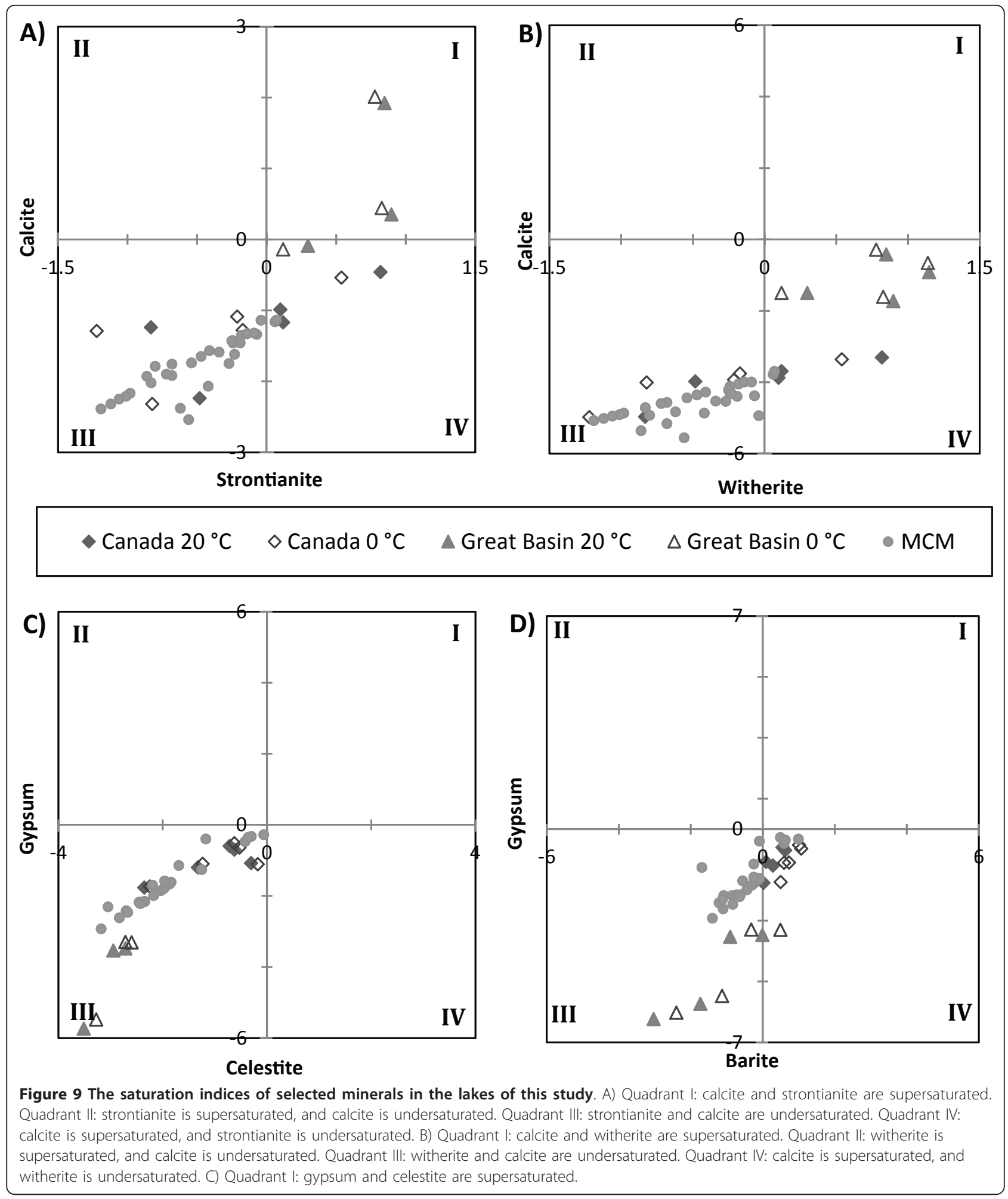

both lobes of Lake Bonney are undersaturated in barite but become supersaturated at and below the chemocline (Figure 8). These results suggest that inorganic precipitation of barite may be an important removal mechanism in both the chloride and sulphate lakes with higher TDS as the waters are evapoconcentrated.

Although the solubility of witherite $\left(\mathrm{BaCO}_{3}\right)$ is low, it is rarely observed as a primary mineral, but rather as an 
alteration product of barite [26]. The calculations indicate that witherite is undersaturated in all lakes (Figure 9).

\section{Substitution}

Clearly we are not in a position to evaluate the role of elemental substitution in this study as we have not analyzed the solid phase products. However, as noted above, previous work does suggest that this process could also affect the fate of these minor elements in salt lake systems.

Besides the precipitation of these minor alkali metals and alkaline earths via simple, binary salts as noted previously, the potential exists for their removal via substitution into more major element salts, such as $\mathrm{CaCO}_{3}$ and $\mathrm{CaSO}_{4} \cdot 2 \mathrm{H}_{2} \mathrm{O}$. The precipitation of calcite is the first geochemical divide encountered during most brine evolution [1]. The divalent elements $\mathrm{Sr}\left(\mathrm{K}_{\mathrm{d}}=0.182\right)$ and $\mathrm{Ba}\left(\mathrm{K}_{\mathrm{d}}=\right.$ 0.0195), have low $K_{d}$ values within calcite and therefore do not readily substitute into it [33]. However, these minerals may be more readily substituted for $\mathrm{Ca}$ in aragonite. It has also been demonstrated that inorganic aragonite, particularly at lower salinities, can accommodate approximately 4.5 times more Li than calcite [34]. Small amounts of $\mathrm{Sr}$ substitution can occur into gypsum and anhydrite, but this substitution is more pronounced during rapid precipitation [26].

With the exception of Abert Lake, which has no detectable alkalinity, the Great Basin lakes are supersaturated with respect to calcite, and the saturation indices are higher at $20^{\circ} \mathrm{C}$ than at $0^{\circ} \mathrm{C}$. Walker, Mono, and Goose Lakes are supersaturated with aragonite at $0^{\circ} \mathrm{C}$ and $20^{\circ} \mathrm{C}$, but Pyramid Lake only supersaturated at $20^{\circ} \mathrm{C}$ (Table 1 ). In Mono Lake, calcite and aragonite precipitate around calcium enriched springs discharging into the carbonate rich lake water [35]. In addition to aragonite and calcite, it has been noted that metastable ikaite $\left(\mathrm{CaCO}_{3} \cdot 6 \mathrm{H}_{2} \mathrm{O}\right)$ precipitates along the shore during the winter months [36]. During the warmer months, ikaite is transformed into either $\mathrm{CaCO}_{3}$ or gaylussite $\left(\mathrm{Na}_{2} \mathrm{Ca}\left(\mathrm{CO}_{3}\right) 2 \cdot 5 \mathrm{H}_{2} \mathrm{O}\right)$ [37]. $\mathrm{Sr}$ and/or $\mathrm{Ba}$ may replace $\mathrm{Ca}$ in ikaite and be retained as it is transformed into calcite, aragonite, vaterite, or gaylussite.

Although currently undocumented, given the near freezing temperatures in the McMurdo Dry Valley lakes, ikaite precipitation could form and act as a mechanism for the removal of minor alkaline earth elements. Most occurrences of ikaite have been found in cold, anoxic marine sediments and it is also debatably linked to high orthophosphate concentrations $[36,38]$. Because orthophosphate was not included in the model calculations, we are unable to quantify the saturation indices of the waters in this study. However, previous work suggests that the MCM lakes are suitable environments for ikaite formation, especially since the $\mathrm{PO}_{4}$ concentration increases with depth in most of these lakes [39]. For example, the water below 9 meters in Lake Fryxell is anoxic, and dissolved phosphorous concentrations increase with depth in the lake [40]. These qualities in addition to temperatures circa $2^{\circ} \mathrm{C}$ at the bottom of Lake Fryxell should provide favorable conditions for ikaite formation. Additionally, in the deep, hypersaline waters of the ice-covered dry valley lakes, Vanda (in Wright Valley to the north), Bonney and Hoare may also present suitable environments for ikaite precipitation, as ikaite has been shown to form in hypersaline inclusions in Antarctic sea ice [41].

Our modelling suggests that the MCM lakes are undersaturated with respect to mirabilite (Table 1 and Figure 8). Mirabilite and gypsum have been shown to play a critical role in the evolution of $\mathrm{Cl}$ brines under freezing conditions $[42,43]$. In sub-zero conditions, mirabilite $\left(\mathrm{Na}_{2} \mathrm{SO}_{4}\right.$. $10 \mathrm{H}_{2} \mathrm{O}$ ) is the first mineral to precipitate at $-7.3^{\circ} \mathrm{C}$ [42]. The lowest temperature observed in the MCM lakes is $-3.91^{\circ} \mathrm{C}$ in West Lake Bonney, indicating that the current temperatures in the MCM lakes perhaps are unfavorable for mirabilite precipitation. The McMurdo Dry Valley Lakes are predominately undersaturated with respect to calcite and aragonite, thus direct incorporation of $\mathrm{Ba}$ or $\mathrm{Sr}$ into aragonite or calcite crystals is unlikely. Calcium-sulphate minerals are also undersaturated, but in some instances, supersaturated with barite. All this suggests that $\mathrm{Sr}$ and $\mathrm{Ba}$ are not being removed by ionic substitution of calcium in calcite, aragonite, gypsum, or anhydrite.

The Canadian lakes in this study are mostly undersaturated with respect to calcite with the exceptions of Waldsea Lake (at $20^{\circ} \mathrm{C}$ and $0^{\circ} \mathrm{C}$ ) and Little Manitou and Deadmoose Lakes at $20^{\circ} \mathrm{C}$. This suggests that seasonal "whitings" of $\mathrm{CaCO}_{3}$ could be a potential sink for minor elements such as Sr. Aragonite has been attributed to whiting events in Waldsea and Deadmoose Lakes when the lakes are at moderate salinity and, during higher salinity periods, the lakes are capable of producing gypsum, aragonite, magnesite, and dolomite precipitates [44,45]. These calculations indicate that the removal of minor elements through the precipitation of gypsum, aragonite, and dolomite may vary spatially and temporally within these systems. The PHREEQ calculations indicate magnesite is supersaturated in all of the Saskatchewan lakes at high and low temperatures, but only Waldesa Lake is supersaturated with respect to aragonite (Table 1).

Due to their similar charges, ionic radii, and electronegativities, $\mathrm{Rb}$ can replace $\mathrm{K}$ in most crystal lattices. Evaporitic minerals such as carnallite and sylvite may incorporate $\mathrm{Rb}$, but the precipitation of these salts is limited due to their very high solubility. For example, during the final stages of seawater evaporation, $\mathrm{Rb}$ preferentially concentrates in carnallite at concentrations of up to $300 \mathrm{ppm}$ [46]. During these final stages, other highly soluble salts such as the chlorides and borates reach saturation. The solubility of lithium salts are so high that it concentrates beyond 
bischofite precipitation and may be incorporated in halite, polyhalite, carnallite, sylvites, and borates $[26,47,48]$. Lithium does also occur in halite and other last-precipitating $\mathrm{Na}$ and $\mathrm{K}$ rich salts. At some point during the end stages of evapoconcentration and halite precipitation, all strontium is removed from the brine as $\mathrm{SrCl}$ because the solubility of $\mathrm{SrCl}$ decreases dramatically in the presence of $\mathrm{NaCl}$ [26]. Although the lakes in this study are at various stages of brine evolution, there is no evidence to suggest that $\mathrm{Rb}$ or $\mathrm{Li}$ are being removed from the lakes as binary salts as all lakes in the study are grossly undersaturated with respect to halite, let alone the more soluble salts, carnallite and sylvite.

\section{The potential importance of biogenic precipitation}

Celestite precipitation may occur inorganically or through biological activity. In freshwater systems, cyanobacteria have been shown to mediate the formation of celestite and strontianite [49]. Strontium depletion in the upper ocean has been ascribed to the production of a celestite skeleton by surface-dwelling acantharia [50]. The death and decomposition of these organisms can also facilitate in the precipitation of barite [51]. A strong correlation between barium and nutrient concentration in the surface water of the oceans suggests biotic control of Ba distribution in seawater $[28,52]$. Although barite production is common in the open ocean, it functions as more of a transport mechanism rather than a permanent sink of barium as approximately $85 \%$ is released into the deep ocean during the breakdown and mineralization of organic matter [53]. This dissolution of barite is also evidenced by a small barium concentration maximum at the $\mathrm{O}_{2} / \mathrm{H}_{2} \mathrm{~S}$ interface in the Black Sea [30]. Strontium also has been shown to be influenced by biogeochemical processes in the marine environment and in some lacustrine environments. Although these ecosystems are quite different than the lakes in this study, biologically mediated transport cannot be ruled out as a process occurring in the systems studied here. Clearly more work needs to be done in the investigation of biological removal of these minor elements in salt lake systems.

\section{Conclusions}

This study has elucidated potential controls on the concentrations of minor elements in a number of saline, closed-basin lakes. In all the anionic water types (i.e. carbonate, sulphate and chloride), lithium and rubidium appear to behave conservatively and are the result of solute input and evapoconcentration. Unlike this "conservative" behaviour of lithium and rubidium, strontium and barium do not behave conservatively. Thermodynamic calculations suggest they are removed by different mechanisms depending on brine type. Strontium appears to be depleted in sulphate and carbonate brines. In the carbonate brines of the Great Basin, Sr may be removed as strontianite $\left(\mathrm{SrCO}_{3}\right)$ or substituted for $\mathrm{Ca}$ in $\mathrm{CaCO}_{3}$ minerals such as ikaite, or especially aragonite. Strontium may be removed from the sulphate-type lakes of Saskatchewan by substitution into $\mathrm{CaCO}_{3}$ as these lakes are supersaturated with respect to both calcite and aragonite. Gypsum is a phase that does not appear to be important for $\mathrm{Sr}$ removal in these lacustrine systems, as it is undersaturated in all of the lakes under investigation. Barite is supersaturated in the McMurdo Dry Valley lakes (chloride-type) and the Saskatchewan lakes indicating that it is a possible important sink for $\mathrm{Ba}$ in these systems. Barite and celestite have been shown to be biologically precipitated in marine systems, and the role of biogenic removal of barium and strontium in these saline lakes warrants further investigation.

\section{Methods \\ Sample collection}

Sample collection bottles for cations were cleaned by soaking the bottles in dilute $\mathrm{HCl}$ and rinsing them with $18 \mathrm{M} \Omega$ water (DI). Anion collection bottles were soaked and rinsed in DI. Stream samples were collected in pre-cleaned Nalgene polyethylene bottles after rinsing the bottles with sample water three times. For the Great Basin and Canadian lakes, only surface samples were collected while depth profiles are available for the Antarctic lakes. Samples were collected from the McMurdo Dry Valley lakes at various depths by lowering a Niskin bottle into a hole drilled into the ice and filling a pre-cleaned Nalgene polyethylene bottle [10]. Great Basin lake samples were collected in pre-cleaned polyethylene bottles. After collection, samples were stored in the dark and sent to The Ohio State University. All samples from Antarctica and the Great Basin were filtered through $0.4 \mu \mathrm{m}$ Nuclepore filters and cation samples were preserved with trace-metal grade $\mathrm{HNO}_{3}$ within 1 week after collection. Samples from Saskatchewan were obtained from the archives at the University of Manitoba [54]. These samples were filtered through $0.4 \mu \mathrm{m}$ Nuclepore filters and preserved with trace-metal grade $\mathrm{HNO}_{3}$ at The Ohio State University.

\section{Laboratory analysis}

Samples and field blanks were analyzed for $\mathrm{Cl}, \mathrm{SO}_{4}, \mathrm{Na}, \mathrm{K}$, $\mathrm{Mg}$, and Ca on Dionex DX-120 Ion Chromatograph (IC) using modified techniques from [55]. Precision of our $\mathrm{Cl}$ and $\mathrm{SO}_{4}$ measurements were $<1$ and $2 \%$, respectively. An independent multi-element standard was analyzed after creating a calibration curve to satisfy quality assurance and quality control. In order to determine the reproducibility of this analytical method, selected samples were analyzed twice.

$\mathrm{Li}, \mathrm{Rb}, \mathrm{Sr}$, and $\mathrm{Ba}$ were quantified using a PerkinElmer Sciex ELAN 6000 Inductively Coupled Plasma Mass spectrometer (ICPMS). An attempt was made to 
quantify Cs concentrations, however all sample were below the detection limit of $0.05 \mu \mathrm{g} / \mathrm{L}$. In addition to sample analysis, the concentrations of $\mathrm{Li}, \mathrm{Rb}, \mathrm{Sr}$, and $\mathrm{Ba}$ were quantified in field blanks (i.e. bottles filled with DI that were transported to the field and processed as samples). Multi-element standards were used for six and eight point calibration curves. Calibration curves were analyzed at least twice in an analytical run. For approximately half of the samples, instrument drift was monitored by using a mid-concentration check standard every 1 to 5 samples. The reproducibility of this standard is illustrated by the relative standard deviations of analyses. Precision of the $\mathrm{Li}, \mathrm{Rb}, \mathrm{Sr}$ and Ba lake water measurements were \pm $1.8 \%, 0.7 \%, 0.7 \%$ and $0.7 \%$, respectively. For the other samples, a $20 \mu \mathrm{g} / \mathrm{L}$ internal standard of $\mathrm{Be}, \mathrm{Co}, \mathrm{La}$, and $\mathrm{Y}$ was implemented for the high salinity samples as a means of allowing the instrument to correct for drift.

Sample aliquots from the McMurdo Dry Valley lakes were analyzed for dissolved inorganic carbon (DIC). The samples were bottled with no head space and preserved with $0.5 \%$ v:v chloroform. The samples were stored chilled in the dark until analysis by either a Lira IRGA with an HP integrator or a Licor 6252 system in the Crary Lab at McMurdo Station, Antarctica [56]. Because the lakes are stratified, DIC replicate measurements below the chemoclines can be compared to illustrate the precision of the method. Alkalinity for the Great Basin and Canadian lakes was analyzed by titration at The Ohio State University. This was achieved by titrating $10 \mathrm{~mL}$ sample aliquots with $1 \mathrm{~N}$ Optima $\mathrm{HCl}$. The precision of this method has been shown to be within $5 \%$ [57].

\section{Geochemical modelling}

Saturation indices were analysed by PHREEQCI, a graphical interface of the thermodynamic model PHREEQ [58,59]. Great Basin and Canadian lake indices were calculated at $20^{\circ} \mathrm{C}$ and $0^{\circ} \mathrm{C}$, and MCM lake indices were calculated based on in-situ temperature measurements. PHREEQ is a general geochemical modelling program that is suitable for many different aqueous environments, but it is necessary to illustrate some of the program's limitations. The default program uses ion associations and DebyeHückle equations to determine the saturation indices of a suite of minerals. Due to the high ionic strength of the solutions in this study, Debye-Hückle equations are not appropriate thus a modified Pitzer database was used. The modifications were the addition of thermodynamic data for reactions and species not included in the Pitzer database [58]. It should be noted that the initial database was a compilation of equilibrium constants and enthalpies from various sources [58]. The thermodynamic information used to modify the Pitzer database was gleaned from the Minteq database included in the PHREEQCI package [59]. Barite was not included in the Minteq database, so its thermodynamic data were tabulated from Stumm and Morgan [60].

\section{Additional material}

Additional file 1: Supplemental data. Reactions, products and phases added to the Pitzer database in PHREEQ.

Additional file 2: Supplemental data. $\mathrm{Li}, \mathrm{Rb}, \mathrm{Sr}$, and $\mathrm{Ba}$ concentrations. Additional file 3: Supplemental data. Major ion, $\mathrm{pH}$, alkalinity, silica and temperature data.

\section{Acknowledgements}

We wish to thank J. Olesik and A. Lutton of the Trace Element Research Laboratory at The Ohio State University for instrumentation usage and their advice on chemical analysis. J.C. Priscu and his MCM-LTER limnology team collected MCM lake samples and the DIC analyses of these samples. W. Last generously contributed samples from Saskatchewan to this work and we are extremely grateful for his enthusiastic support of this work. S. Fortner and J. Barker assisted in GB and MCM sample collection, respectively. K.A. Welch, C. Gardner, and C. Maxwell assisted in major ion and alkalinity analysis. We are also indebted to the following people for their thoughtful comments to the original manuscript from the dissertation of R. Witherow: Ozeas Costa, Bill Green, Anne Carey, and Dave Porinchu. The support of many from the MCM-LTER program, Raytheon, PHI, and DRI made this work possible. The Antarctic portion of this work was funded by NSF-ANT grant \#0423595. Finally, we thank three anonymous reviewers whose comments and suggestions greatly improved the original submission.

\section{Author details}

${ }^{1}$ School of Earth Sciences, The Ohio State University, Columbus, Ohio, USA. 2Byrd Polar Research Center, The Ohio State University, Columbus, Ohio, USA. ${ }^{3}$ Idaho Dept. of Environmental Quality, Coeur d'Alene, Idaho, USA.

\section{Authors' contributions}

This manuscript is modified from a chapter in the Ph.D. dissertation of RW completed at The Ohio State University under the supervision of WBL. RW did the analysis of the minor elements and all the modelling work. WBL helped conceive of the study and participated in the design and coordination of these investigations as well as helped develop the manuscript in all its phases. All the authors have read and approved the final manuscript.

\section{Competing interests}

The authors declare that they have no competing interests.

Received: 15 April 2011 Accepted: 12 October 2011

Published: 12 October 2011

\section{References}

1. Hardie L, Eugster $\mathrm{H}$ : The evolution of closed-basin brines. Fiftieth Anniversary Symposia, Mineralogy and Geochemistry of Non-Marine Evaporites Mineralogical Society of America Special Publication; 1970, 273-290.

2. Eugster HP, Jones BF: Behavior of major solutes during closed-basin brine evolution. Am J Sci 1979, 279(6):609-631.

3. Herezeg AL, Lyons WB: A chemical model for the evolution of Austrialian sodium chloride lake brines. Palaeogeography, Palaeoclimatology, Palaeoecology 1991, 84:43-53.

4. Chinn T: The dry valleys. In Antarctica; the Ross Sea region DSIR Information Series. Edited by: Hatherton T. Department of Scientific and Industrial Research (DSIR); 1990:137-153.

5. Fountain AG, Lyons WB, Burkins MB, Dana GL, Doran PT, Lewis KJ, McKnight DM, Moorhead DL, Parsons AN, Priscu JC, et al: Physical Controls on the Taylor Valley Ecosystem, Antarctica. BioScience 1999, 49(12):961-971.

6. Chinn T: Physical hydrology of the Dry Valley lakes. Antarctic Research Series 1993, 59:1-51. 
7. Conovitz P, McKnight D, MacDonald L, Fountain A, House H: Hydrologic processes influencing streamflow variation in Fryxell Basin, Antarctica. In Antarctic Research Series. Edited by: Priscu J. Washington, DC: American Geophysical Union; 1998:93-108.

8. Clow G, McKay C, Simmons GJ, Wharton R: Climatological observations and predicted sublimation rates at Lake Hoare, Antarctica. Journal of Climate 1988, 1(7):715-728.

9. Green WJ, Angle MP, Chave KE: The geochemistry of antarctic streams and their role in the evolution of four lakes of the McMurdo dry valleys. Geochimica et Cosmochimica Acta 1988, 52(5):1265-1274.

10. Lyons WB, Welch KA, Neumann K, Moorhead D, McKnight DM: Geochemical linkages among glaciers, streams and lakes within the Taylor Valley, Antarctica. In Ecosystem dynamics in a polar desert: the McMurdo Dry Valleys, Antarctica. Edited by: Priscu JC. American Geophysical Union; 1998:77-92.

11. Witherow RA, Lyons WB, Bertler NAN, Welch KA, Mayewski PA, Sneed SB, Nylen T, Handley MJ, Fountain A: The aeolian flux of calcium, chloride and nitrate to the McMurdo Dry Valleys landscape: evidence from snow pit analysis. Antarctic Science 2006, 18(04):497-505.

12. Angino $E$, Armitage $K$, Tash J: A chemical and limonological study of Lake Vanda, Victoria Land, Antarctica. University of Kansas Science Bulletin 1965, 45:1097-1118.

13. Green WJ, Lyons WB: The Saline Lakes of the McMurdo Dry Valleys, Antarctica. Aquatic Geochemistry 2009, 15(1-2):321-348.

14. Jones BF: Geochemical evolution of closed-basin water in the western Great Basin. Proceedings of the Second Symposium on Salt 1966, 181-200.

15. Phillips K, Van Denburgh A: Hydrology and geochemistry of Abert, Summer, and Goose lakes, and other closed basin lakes in south-central Oregon. U. S. Geological Survey; 1971

16. Last W, Ginn F: Saline systems of the Great Plains of western Canada: an overview of the limnogeology and paleolimnology. Saline Systems 2005, 1(1):10.

17. Last WM: Continental brines and evaporites of the northern Great Plains of Canada. Sedimentary Geology 1989, 64(4):207-221.

18. Last WM, Schweyen TH: Sedimentology and geochemistry of saline lakes of the Great Plains. Hydrobiologia 1983, 105(1):245-263.

19. Eugster H, Hardie L: Saline Lakes. In Lakes: Chemistry, Geology, Physics. Edited by: Lerman A. New York, NY; 1978:237-293.

20. Lyons WB, Welch KA: Lithium in waters of a polar desert. Geochimica et Cosmochimica Acta 1997, 61(20):4309-4319.

21. Lyons ZR, Graham EY, Yang WB: Geochemistry of Pyramid Lake sediments: influence of anthropogenic activities and climatic variations within the basin. Environmental Geology 2003, 43(6):688-697.

22. De Lange GJ, Boelrijk NAIM, Catalano G, Corselli C, Klinkhammer GP, Middelburg JJ, Müller DW, Ullman WJ, Van Gaans P, Woittiez JRW: Sulphate-related equilibria in the hypersaline brines of the Tyro and Bannock Basins, eastern Mediterranean. Marine Chemistry 1990, 31(13):89-112.

23. Krumgalz BS, Starinsky A, Pitzer KS: Ion-Interaction Approach: Pressure Effect on the Solubility of Some Minerals in Submarine Brines and Seawater. Journal of Solution Chemistry 1999, 28(6):667-692.

24. Rosen MR: Sedimentological and geochemical constraints in the evolution of Bristol Dry Lake Basin, California, USA. Palaeogeography, Palaeoclimatology, Palaeoecology 1991, 84:229-257.

25. Wood MW, Shaw HF: The geochemistry of celestites from the Yati area near Bristol (UK). Chemical Geology 1976, 17:179-153.

26. Sonnenfeld P: Brines and Evaporites Orlando, Florida: Academic Press; 1984

27. Rushdi Al, McManus J, Collier RW: Marine barite and celestite saturation in seawater. Marine Chemistry 2000, 69(1-2):19-31.

28. Dehairs $F$, Chesselet $R$, Jedwab J: Discrete suspended particles of barite and the barium cycle in the open ocean. Earth and Planetary Science Letters 1980, 49(2):528-550.

29. Schijf J: Alkali elements $(\mathrm{Na}, \mathrm{K}, \mathrm{Rb})$ and alkaline earth elements $(\mathrm{Mg}, \mathrm{Ca}$ $\mathrm{Sr}, \mathrm{Ba}$ ) in the anoxic brine of Orca Basin, northern Gulf of Mexico. Chemical Geology 2007, 243(3-4):255-274.

30. Falkner KK, Klinkhammer GP, Bowers TS, Todd JF, Lewis BL, Landing WM, Edmond JM: The behavior of barium in anoxic marine waters. Geochimica et Cosmochimica Acta 1993, 57(3):537-554

31. Chan $L H$, Drummond D, Edmond JM, Grant B: On the barium data from the Atlantic GEOSECS expedition. Deep Sea Research 1977, 24(7):613-649.
32. Dehairs F, Lambert C, Chesselet R, Risler N: The biological production of marine suspended barite and the barium cycle in the Western Mediterranean Sea. Biogeochemistry 1987, 4(2):119-140.

33. Rimstidt JD, Balog A, Webb J: Distribution of trace elements between carbonate minerals and aqueous solutions. Geochimica et Cosmochimica Acta 1998, 62(11):1851-1863.

34. Marriott CS, Henderson GM, Crompton R, Staubwasser M, Shaw S: Effect of mineralogy, salinity, and temperature on $\mathrm{Li} / \mathrm{Ca}$ and $\mathrm{Li}$ isotope composition of calcium carbonate. Chemical Geology 2004, 212(1-2):5-15.

35. Jehl J: Tufa formation at Mono Lake, California. California Geology 1983, 36(3)

36. Bischoff JL, Fitzpatrick JA, Rosenbauer RJ: The Solubility and Stabilization of Ikaite $\left(\mathrm{CaCO}_{3} \cdot 6 \mathrm{H}_{2} \mathrm{O}\right)$ from $0^{\circ}$ to $25^{\circ} \mathrm{C}$ : Environmental and Paleoclimatic Implications for Thinolite Tufa. The Journal of Geology 1993, 101(1):21-33.

37. Bischoff JL, Stine S, Rosenbauer RJ, Fitzpatrick JA, Stafford TW Jr: Ikaite precipitation by mixing of shoreline springs and lake water, Mono Lake, California, USA. Geochimica et Cosmochimica Acta 1993, 57(16):3855-3865.

38. Omelon $\mathrm{CR}$, Pollard $\mathrm{WH}$, Marion $\mathrm{GM}$ : Seasonal formation of ikaite $\left(\mathrm{CaCO}_{3}\right.$ $\left..6 \mathrm{H}_{2} \mathrm{O}\right)$ in saline spring discharge at Expedition Fiord, Canadian High Arctic: Assessing conditional constraints for natural crystal growth. Geochimica et Cosmochimica Acta 2001, 65(9):1429-1437.

39. Herbei R, Berry Lyons W, Laybourn-Parry J, Gardner C, Priscu JC, McKnight DM: Physiochemical properties influencing biomass abundance and primary production in Lake Hoare, Antarctica. Ecological Modelling 2010, 221(8):1184-1193.

40. Green WJ, Gardner TJ, Ferdelman TG, Angle MP, Varner LC, Nixon P. Geochemical processes in the Lake Fryxell Basin (Victoria Land, Antarctica). Hydrobiologia 1989, 172(1):129-148.

41. Dieckmann GS, Nehrke G, Papadimitriou S, Göttlicher J, Steininger R, Kennedy H, Wolf-Gladrow D, Thomas DN: Calcium carbonate as ikaite crystals in Antarctic sea ice. Geophys Res Lett 2008, 35(8):L08501.

42. Marion GM, Farren RE, Komrowski AJ: Alternative pathways for seawater freezing. Cold Regions Science and Technology 1999, 29(3):259-266.

43. Marion GM: A theoretical evaluation of mineral stability in Don Juan Pond, Wright Valley, Victoria Land. Antarctic Science 1997, 9(01):92-99.

44. Last WM, Schweyen TH: Late Holocene history of Waldsea Lake, Saskatchewan, Canada. Quaternary Research 1985, 24(2):219-234.

45. Last WM, Slezak L: Paleohydrology sedimentology, and geochemistry of two meromictic saline lakes in southern Saskatchewan. Geographie Physique et Quaternaire 1986, XL:5-15.

46. Hosler W: Trace elements and isotopes in evaporites. Marine Minerals Reviews in Mineralology Washington DC: Mineralogical Society of America; 1979, 295-346

47. Lepeshkov IN, Shaposhnikoova AN, Zaitseva IS: Lithium distribution in natural salts. Geokhimya 1970, 11:1322-1328.

48. Zherebtsova IK, Volkova NN: Experimental study of behavior of trace elements in the process of natural solar evaporation of Black Sea water and Sasyk-sivash brine. Geochemistry International 1966, 3:656-670.

49. Schultze-Lam S, Beveridge TJ: Nucleation of Celestite and Strontianite on a Cyanobacterial S-Layer. Appl Environ Microbiol 1994, 60(2):447-453.

50. Bernstein RE, Byrne RH, Betzer PR, Greco AM: Morphologies and transformations of celestite in seawater: The role of acantharians in strontium and barium geochemistry. Geochimica et Cosmochimica Acto 1992, 56(8):3273-3279.

51. Bernstein RE, Byrne RH: Acantharians and marine barite. Marine Chemistry 2004, 86(1-2):45-50.

52. Moore WS, Falkner KK: Cycling of radium and barium in the Black Sea. Journal of Environmental Radioactivity 1999, 43(2):247-254.

53. Wolgemuth K, Broecker WS: Barium in sea water. Earth and Planetary Science Letters 1970, 8(5):372-378.

54. Last W: Chemical composition of saline and subsaline lakes of the northern Great Plains, western Canada. International Journal of Salt Lake Research 1992, 1(2):47-76.

55. Welch KA, Lyons WB, Graham E, Neumann K, Thomas JM, Mikesell D: Determination of major element chemistry in terrestrial waters from Antarctica by ion chromatography. Journal of Chromatography A 1996, 739(1-2):257-263.

56. MCM-LTER. Limnological Methods for the MCMurdo Long Term Ecological Research Program 2007. 
57. Alkalinity. Standard Methods 1999, 2320.

58. Parkhurst D, Appelo C: PHREEQC, Water-Resources Investigations Report 99-4259. Denver, CO: U.S. Geological Survey, U.S. Department of the Interior; 1999.

59. Charlton S, Parkhurst D: PHREEQCl; a graphical user interface to the geochemical model PHREEQC. U. S. Geological Survey, Denver, CO; 2002.

60. Stumm W, Morgan JJ: Aquatic Chemistry John Wiley \& Sons; 1996.

61. Pilson MEQ: An Introduction to the Chemistry of the Sea New Jersey: Prentice Hall; 1998.

doi:10.1186/1746-1448-7-2

Cite this article as: Witherow and Lyons: The fate of minor alkali

elements in the chemical evolution of salt lakes. Saline Systems 2011 7:2.

Submit your next manuscript to BioMed Central and take full advantage of:

- Convenient online submission

- Thorough peer review

- No space constraints or color figure charges

- Immediate publication on acceptance

- Inclusion in PubMed, CAS, Scopus and Google Scholar

- Research which is freely available for redistribution

Submit your manuscript at www.biomedcentral.com/submit 